\title{
Systematic Review on the Functional Status of Elderly Hip Fracture Patients using Katz Index of Activity of Daily Living (Katz ADL) Score
}

\author{
Sharkawi MA ${ }^{\mathrm{a}}$, Zulfarina $\mathrm{SM}^{\mathrm{a}}$, Aqilah-SN SMZ ${ }^{\mathrm{b}}$, Isa NM ${ }^{\mathrm{a}}$, Sabarul AM ${ }^{\mathrm{b}}$, Nazrun $\mathrm{AS}^{\mathrm{a}}$ \\ ${ }^{a}$ Department of Pharmacology, Pusat Perubatan Universiti Kebangsaan Malaysia (PPUKM), Jalan Yaacob \\ latif, Bandar Tun Razak, Cheras, 56000, Kuala Lumpur, Malaysia. \\ ${ }^{b}$ Department of Orthopedics, Pusat Perubatan Universiti Kebangsaan Malaysia (PPUKM), Jalan Yaacob latif, \\ Bandar Tun Razak, Cheras, 56000, Kuala Lumpur, Malaysia.
}

\begin{abstract}
Hip fractures cases are common in elderly population. After a hip fracture, around $80 \%$ of patients were unable to carry out at least one independent activity of daily living (ADL). This review attempted to provide an evidence-based literature on ADL of elderly hip fracture patients. A computerised literature search using Medline (OVID) and Scopus databases were conducted to identify relevant studies on ADL of elderly hip fracture patients that was assessed with Katz ADL score. Only articles that fulfilled the inclusion criteria were included in this review. Initial search identified 314 potentially relevant articles but after careful screening, only 5 full-text articles were selected for the present review. Three studies showed an increase dependent level of the patients' ADL after hip fractures. Two studies showed not more than half of the patients were unable to regain their pre-fracture ADL level after one year of hip fracture incidence. Feeding/eating showed the highest independent activity while bathing was the lowest independent activity among patients. In conclusion, elderly hip fracture patients have declined ADL with the risk that they may never regain their pre-fracture ADL level.
\end{abstract}

Key words: Hip fracture, functional status, Activity of daily living, Katz ADL

\section{INTRODUCTION}

Activity of Daily Living (ADL) can be divided into simple or basic (BADL), and more complex, instrumental activity of daily living (IADL). BADL concerns functional mobility and personal care such as ambulation, transfer and bed mobility, toileting, feeding, hygiene, dressing and bathing. IADL involved complex activities such as shopping, cooking, housekeeping, laundry, use of transportation, managing money, managing medication and the use of the telephone. There are several assessment tools which can be used to assess ADL performance and functional status such as The PULSES Profile (PULSES), Katz Index of activity of Daily Living (Katz ADL), Kenny Self-Care Evaluation and The Barthel Index. Among these

Corresponding author:

Professor Dr. Ahmad Nazrun Shuid

Jabatan Farmakologi, Tingkat 17, Bangunan

Praklinikal,

Pusat Perubatan Universiti Kebangsaan

Malaysia (PPUKM),

Jalan Yaacob latif, Bandar Tun Razak, Cheras,

56000 Kuala Lumpur, Malaysia.

Telephone: 603-91459576;

Fax: 603-26938205;

Email:anazrun@yahoo.com tools, Katz ADL was the main tool used to measure and assess functional performance in patients ${ }^{1,2}$. It was developed to assess functional outcome in elderly by rating the subjects as dependent or independent of the six scales of basic activities which are bathing, dressing, toileting, transferring, continence and feeding (Figure 1$)^{3}$. It is sensitive to detect declining health status but it has limited ability to measure small incremental changes during rehabilitation. Katz ADL was used extensively and consistently to evaluate functional status of elderly population ${ }^{4}$.

The outcomes of Katz ADL are dichotomous. A patient who could perform an activity without supervision, direction or assistance is scored " 1 point (independence)". If a patient required supervision, direction or assistance to perform an activity, he or she is scored "0 point (dependent)". A patient who cannot perform an activity at all or require total care is also scored " 0 point (dependent)" 5 . Reijneveld et al., (2007) showed that Katz ADL was a valid tool to measure functional outcome among elderly patients in the Turkish, Moroccan and Dutch population $^{2}$. 
Katz Index of Independence in Activities of Daily Living

\begin{tabular}{|c|c|c|}
\hline $\begin{array}{l}\text { Activities } \\
\text { Points (1 or } 0)\end{array}$ & $\begin{array}{l}\text { Independence } \\
\qquad \text { (1 Point) } \\
\text { NO supervision, direction or } \\
\text { personal assistance }\end{array}$ & $\begin{array}{l}\text { Dependence } \\
\text { (0 Points) } \\
\text { WITH supervision, direction, } \\
\text { personal assistance or total care }\end{array}$ \\
\hline $\begin{array}{c}\text { BATHING } \\
\text { Points: }\end{array}$ & $\begin{array}{l}\text { (1 POINT) Bathes self completely } \\
\text { or needs help in bathing only a } \\
\text { single part of the body such as the } \\
\text { back, genital area or disabled } \\
\text { extremity }\end{array}$ & $\begin{array}{l}\text { ( } 0 \text { POINTS) Need help with bathing } \\
\text { more than one part of the body, getting } \\
\text { in or out of the tub or shower. } \\
\text { Requires total bathing }\end{array}$ \\
\hline $\begin{array}{c}\text { DRESSING } \\
\text { Points: }\end{array}$ & $\begin{array}{l}\text { (1 POINT) Get clothes from } \\
\text { closets and drawers and puts on } \\
\text { clothes and outer garments } \\
\text { complete with fasteners. May have } \\
\text { help tying shoes. }\end{array}$ & $\begin{array}{l}\text { (0 POINTS) Needs help with dressing } \\
\text { self or needs to be completely dressed. }\end{array}$ \\
\hline $\begin{array}{l}\text { TOILETING } \\
\text { Points: }\end{array}$ & $\begin{array}{l}\text { (1 POINT) Goes to toilet, gets on } \\
\text { and off, arranges clothes, cleans } \\
\text { genital area without help. }\end{array}$ & $\begin{array}{l}\text { (0 POINTS) Needs help transferring to } \\
\text { the toilet, cleaning self or uses bedpan } \\
\text { or commode. }\end{array}$ \\
\hline $\begin{array}{l}\text { TRANSFERRING } \\
\text { Points: }\end{array}$ & $\begin{array}{l}\text { (1 POINT) Moves in and out of } \\
\text { bed or chair unassisted. } \\
\text { Mechanical transfer aids are } \\
\text { acceptable }\end{array}$ & $\begin{array}{l}\text { (0 POINTS)Needs help in moving } \\
\text { from bed to chair or requires a } \\
\text { complete transfer. }\end{array}$ \\
\hline $\begin{array}{l}\text { CONTINENCE } \\
\text { Points: }\end{array}$ & $\begin{array}{l}\text { (1 POINT) Exercises complete self } \\
\text { control over urination and } \\
\text { defecation. }\end{array}$ & $\begin{array}{l}\text { (0 POINTS) Is partially or totally } \\
\text { incontinent of bowel or bladder }\end{array}$ \\
\hline $\begin{array}{r}\text { FEEDING } \\
\text { Points: }\end{array}$ & $\begin{array}{l}\text { (1 POINT) Gets food from plate } \\
\text { into mouth without help. } \\
\text { Preparation of food may be done } \\
\text { by another person. }\end{array}$ & $\begin{array}{l}\text { (0 POINTS) Needs partial or total help } \\
\text { with feeding or requires parenteral } \\
\text { feeding. }\end{array}$ \\
\hline
\end{tabular}

Figure 1: Example of Katz ADL tools. Adapted from Wallace M, Shelkey M. Katz Index of Independence in Activities of Daily Living. J Gerontol Nurs 1999; 25: 8-9.

Hip fracture can be defined as a bone fracture that occurs at the proximal (upper) site of the femur, at the outer area where femoral head (ball) meets the acetabulum (socket) within the pelvis. Hip fracture can be generally classified into three major types based on anatomical sites: femoral neck, intertrochanteric and subtrochanteric fractures ${ }^{6,7}$. Hip fracture incidence is common especially in elderly women and is associated with significant mortality, morbidity and disability. Hip fracture can be treated either by surgical treatment or nonoperative management.

Examples of surgical treatment for hip fracture are internal fixation, hemiarthoplasty or total hip replacement, extramedullary implants and intramedullary nail. If the patients have poor medical condition, not physically fit for an operation or too old, non-operative management is an alternative appropach for the treatment of hip fracture ${ }^{8,9}$.

The total number of hip fracture cases in Asia has increased every year. In Japan, there were 851, 901 and 1059 cases reported in the year 2004, 2005 and 2006 respectively. In Korea, hip fracture cases in women have increased from 250.9 per 100000 person in 2001 to 262.8 per 100000 in 2004. Singapore was reported to have the highest incidence of hip fracture in $\mathrm{Asia}^{10}$. The last report on fracture cases in Malaysia was in 1997, which focused on cases in elderly of more than 50 years of age. The main type of fracture reported was hip fracture with the incidence of 90 per 100,000 individuals ${ }^{11}$.

Hip fracture is a major public health problem due to its increasing prevalence, health consequences and economics costs. It was estimated that after one year of fracture, around $25 \%$ to $75 \%$ of hip fracture patients who were independent before fracture were unable to walk independently and end up not achieving the pre-fracture level of independence.

Hip fracture was also associated with high co-morbidity, mortality rate and may cause permanent disability and dependency. It was shown that $18 \%$ to $33 \%$ of elderly hip fracture patient died after one year of hip fracture ${ }^{12,13,14}$.

This review attempted to provide an evidencebased literature on ADL of elderly hip fracture patients. Only Katz ADL was selected as the standard assessment tool for functional outcome of ADL. 


\section{METHODOLOGY}

\section{Searching Article}

Computerized literature search of articles related to Katz ADL score of hip fracture patients was conducted using Medline (OVID) and SCOPUS databases. Several keywords were used and combined together. Below are the keywords used when searching for relevant articles:

1. Hip* OR *femur* OR *femoral* $O R$ acetabulum OR pelvi* OR thighbone* OR *capsular* OR *trochanter*

2. Activit* of daily living $O R{ }^{*} A D L^{*}$

3. Fracture*

4. Katz

\section{Selection of Research Articles}

Article generated from both databases must fulfil both the inclusion and exclusion criteria of the present systematic review. All articles from the search database were limited to English language.

Inclusion Criteria:

Sample or subject must be more than 50 years of age, hip fracture patients and ADL assessed using Katz ADL score. In order to make comparison and analyses possible, only studies using Katz ADL score was chosen for this systematic review.

\section{Exclusion Criteria:}

Studies using subjects below 50 years of age, studies which were not related with the objective of this systematic review, intervention studies and review articles were all excluded.

\section{Data Extraction and Management}

All articles generated from Medline (OVID) and SCOPUS databases, underwent three phases of screening. Firstly, the titles of articles were screened and any articles with titles that did not match the inclusion criteria were excluded. In the second phase, abstracts of the remaining articles were screened. If they did not fulfil the inclusion criteria, the articles were excluded.
In the final stage of screening, the full text of the remaining articles was retrieved. The reviewers read thoroughly and reviewed all the articles to confirm their suitability and to ensure that they have met the inclusion and exclusion criteria.

Any reviews (narrative and systematic) or metaanalysis were excluded. Duplicates were removed throughout the screening phases. All the authors were involved in the screening phases. When there were differences in opinion, the authors would discuss to arrive to a consensus.

The screening phase was followed by the extraction phase, where all the data were extracted using a standardised data collection form. The following data was extracted:

1. Study design

2. Subject or sample population

3. Description of study method to measure ADL and duration of follow up

4. Description of the study result.

\section{RESULTS}

\section{Search Result}

Using the keywords mentioned above, 288 articles were retrieved from Medline OVID and 26 articles from SCOPUS databases. After the first screening, there were 26 articles left from Medline OVID and 10 articles from SCOPUS databases.

With the removal of the duplicates, there were 26 and 7 articles left from the Medline Ovid and SCOPUS databases, respectively. The abstracts of the 33 articles were independently screened by three reviewers.

Only 5 articles were left after excluding articles that did not fulfil the inclusion and exclusion criteria, reporting intervention study, or the parameters wanted did not form the main study. The full text of all 5 articles was successfully retrieved fur further assessment and data extraction. All reviewers agreed that all the 5 articles should be included in the systematic review. Figure 2 showed the flow chart of study selection and search result. 


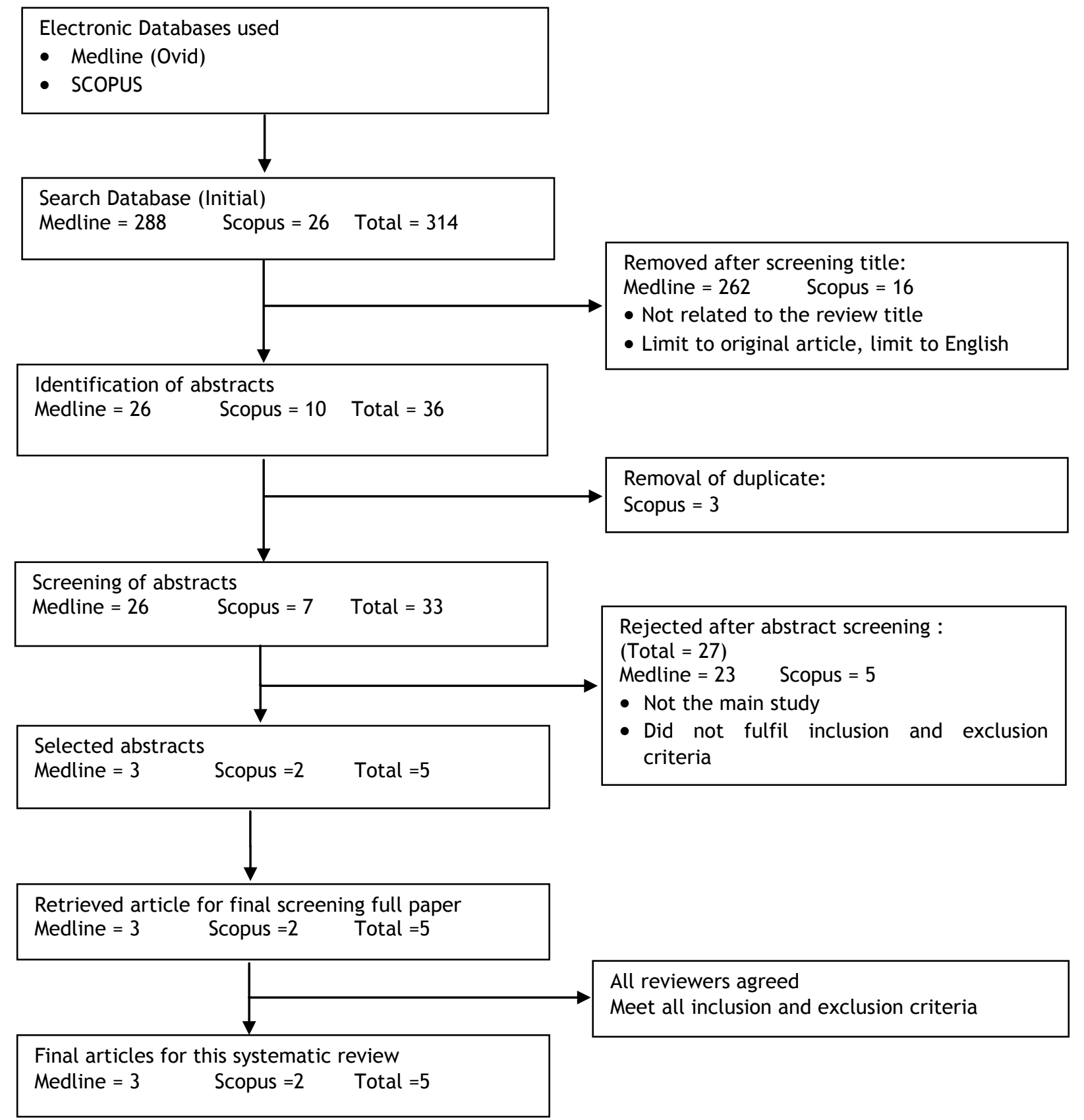

Figure 2: Flow chart of selection process for the article

\section{Characteristic of study}

Characteristic of the studies included were summarized in Table 1. The designs of the selected studies were exploratory study by Curry et al. ${ }^{15}$, retrospective descriptive study by Garcia et al. ${ }^{16}$, prospective study by Svensson et al. ${ }^{17}$, prospective, longitudinal study by Wollinsky et al. ${ }^{18}$ and prospective, consecutive study by Mehul et al. ${ }^{19}$. All the studies were published from 1996 to 2006. Two of the studies were published in $1996^{17,18}$. Another two were published in $2003^{15,19}$ and one study was published in $2006^{16}$. Two studies have the sample size of less than 100 subjects $^{15,16}$. Two studies have the sample size of more than 100 and up to 1000 subjects ${ }^{17,19}$. Only one study has the of sample size of more than 1000 subjects $^{18}$. The age of the subjects for four of the studies were between 50 to 100 years old ${ }^{15,16,19}$. In another study all the samples were more than 70 years old ${ }^{18}$. Based on the gender, four articles focused on both gender, male and female ${ }^{16,17,18,19}$. Only one article focused on female subjects only ${ }^{15}$. One study followed up its subjects for six months to four years after fracture ${ }^{15}$. The rest of the studies followed up their subjects for 1 year ${ }^{16,17,19}$ or 8 years after fracture ${ }^{18}$. Details of the study description were summarised in Table 2. 
Table 1: Characteristic of Study

\begin{tabular}{|c|c|}
\hline Study Characteristic & Number of study \\
\hline \multicolumn{2}{|l|}{ Study Design } \\
\hline Exploratory Design & 1 \\
\hline Prospective study & 3 \\
\hline Retrospective study & 1 \\
\hline \multicolumn{2}{|l|}{ Year of Publication } \\
\hline $\begin{array}{l}\leq 2000 \\
>2000\end{array}$ & $\begin{array}{l}2 \\
3\end{array}$ \\
\hline \multicolumn{2}{|l|}{ Sample Size } \\
\hline $\begin{array}{l}\leq 100 \\
101-1000 \\
>1000\end{array}$ & $\begin{array}{l}2 \\
2 \\
1\end{array}$ \\
\hline \multicolumn{2}{|l|}{ Age Range } \\
\hline $\begin{array}{l}50-\leq 100 \\
50-\geq 100 \\
\geq 70\end{array}$ & $\begin{array}{l}3 \\
1 \\
1\end{array}$ \\
\hline \multicolumn{2}{|l|}{ Gender } \\
\hline $\begin{array}{l}\text { Male and female } \\
\text { Female only } \\
\text { Male only }\end{array}$ & $\begin{array}{l}4 \\
1 \\
0\end{array}$ \\
\hline \multicolumn{2}{|l|}{ Duration of Follow up } \\
\hline $\begin{array}{l}6 \text { months to } 4 \text { years } \\
>1 \text { year }\end{array}$ & $\begin{array}{l}1 \\
4\end{array}$ \\
\hline
\end{tabular}

Table 2: Study Description

\begin{tabular}{|c|c|c|c|c|c|c|}
\hline Title & Authors & $\begin{array}{l}\text { Study } \\
\text { Design }\end{array}$ & $\begin{array}{l}\text { Year of } \\
\text { publication }\end{array}$ & $\begin{array}{l}\text { Sample or } \\
\text { subject }\end{array}$ & $\begin{array}{l}\text { Method } \\
\text { of ADL } \\
\text { assessment }\end{array}$ & Results \\
\hline $\begin{array}{l}\text { Functional } \\
\text { status in } \\
\text { older } \\
\text { women } \\
\text { following } \\
\text { hip } \\
\text { fracture }\end{array}$ & $\begin{array}{l}\text { Curry et } \\
\text { al., [15] }\end{array}$ & $\begin{array}{l}\text { Exploratory } \\
\text { Design }\end{array}$ & 2003 & $\begin{array}{l}\text { Sample size: } \\
23 \text { Caucasian } \\
\text { women } \\
\text { Age of } \\
\text { subjects: } \\
65-95 \text { years } \\
\text { old. }\end{array}$ & $\begin{array}{l}\text { Duration of } \\
\text { follow up: } 6 \\
\text { months to } 4 \\
\text { years after } \\
\text { fracture. } \\
\text { All subjects } \\
\text { were } \\
\text { interviewed. }\end{array}$ & $\begin{array}{l}18 \text { out of } 23 \text { subjects achieved } \\
\text { maximum independence score } \\
\text { of the Katz ADL scale at least } \\
\text { six month after fracture. } \\
\text { Eating was the activity that } \\
\text { showed the highest } \\
\text { independent level in } 18 \\
\text { subjects. } \\
\text { Bathing is the activity that } \\
\text { needs the most help } \\
\text { ( } 5 \text { subjects). } \\
3 \text { subjects need help in } \\
\text { dressing and continence, } 2 \\
\text { with toileting and } 1 \text { with } \\
\text { transferring. } \\
\text { There is no significant } \\
\text { difference between the ability } \\
\text { to perform ADL at time of } \\
\text { follow up with age, length of } \\
\text { physical or rehabilitation } \\
\text { therapy, number of } \\
\text { pre-existing conditions and } \\
\text { numbers of co morbidities } \\
\text { after fracture. }\end{array}$ \\
\hline
\end{tabular}




\section{Katz ADL Score}

Two studies from this systematic review had attempted to briefly describe each score scale and dependency status of the basic activity in Katz ADL that was used to assess hip fracture patients ${ }^{15,16}$. The other three studies did not describe the scale used in Katz ADL score ${ }^{17,18,19}$. Curry et al., (2003) showed that eating was the most independent activity among hip fracture patients, while bathing is the activity that required the most assistance ${ }^{15}$. Meanwhile, Garcia et al., (2006) reported improvement in the dependent level of $A D L$ with physical ambulation showing the most improvement while feeding/eating showed the least improvement in dependency compared to other activities $^{16}$. Three other studies ${ }^{16,17,18}$ reported better independence level of $A D L$ among hip fracture patients after the fracture. While, another two studies ${ }^{15,19}$ reported that a proportion of hip fracture patients failed to regain their ADL pre-fracture level.

\section{Duration of follow up and ADL}

Three studies reported that after one year of follow up, there were hip fracture patients who did not fully recover their basic $A D L^{16,17,19}$. In fact, several of these patients had lower ADL compared to their prefracture level. Wolinsky et al., (1997) found that there was an increase in the mean of functional new limitation for $A D L$ after six years of fracture as compared to baseline ${ }^{18}$. While, Curry et al., (2003) which followed up patients from six months to four years reported that 18 out of 23 patients had already achieved the maximum Katz ADL score (independence in all basic $A D L$ ) at six months after fracture $^{15}$.

\section{Age, Gender and ADL}

Curry et al., (2003) found no significant association between age and the ability to perform ADL. In this study, comparison cannot be made between different genders as the subjects recruited were only Caucasian women ${ }^{15}$. Svensson et al., (1996) also found no relation between ADL function and age or gender. However, the gender distribution in this study was not equal as the number of female patients (170 subjects) far exceeded the male patients (53 subjects) ${ }^{17}$. Wolinsky et al., (1997) had studied a large sample size and followed the subjects prospectively for 8 years. The focus of the study was to compare basic ADL of hip fracture subjects with control subjects. The results showed a significant difference in the mean score of ADL between the groups.

This indicated new functional limitations of $A D L$ in the hip fracture subjects ${ }^{18}$. Garcia et al., (2006) showed that the decline in functional status was association with age (elderly more than 80 years) and male sex ${ }^{16}$. Mehul et al., (2001) reported that elderly hip fracture patients, aged more than 90 years old, were more likely to show reduction in their basic $A \mathrm{AL}^{19}$.

\section{DISCUSSION}

There were only few studies available on the assessment of ADL for hip fracture patients. The focus of this systematic review was to analyse literatures on the ADL of elderly hip fracture patients. Elderly patients were selected as the incidence of hip fractures was high in patients more than 50 years of age ${ }^{20}$. There are several ADL scoring tools available, but this systematic review focused on the main type of tool used for functional assessment of hip fractures, which is Katz ADL. This tool is easy to use and is sensitive enough to give good assessment of ADL. Different tools have different aspect of evaluation and different scoring system. Thus, by standardizing the ADL assessment tool, it allowed comparison to be made between the studies on any changes in ADL. This systematic review was written based on five articles which fulfilled the selection criteria.

They were published from 1996 to 2006. Based on all the five article included in this review, the duration of follow up varied between six months to more than one years. The sample size for two of the studies were below 50 subjects ${ }^{15,16}$. Another 2 studies had over $200^{17}$ and 800 subjects ${ }^{19}$. The largest sample size was recruited in the study by Wolinsky et al., (1997) which had more than 7500 subjects $^{18}$. There is a huge difference in the sample size of the studies, from as few as 23 subjects to more than 7000 subjects. Since, there are limited studies carried out on the ADL of elderly hip fracture patients, all the studies were included. However, caution was taken when interpreting data from studies with smaller sample size. Greater consideration should be given more to studies with adequate and large sample size especially studies by Wollinsky et al., (1997) and Mehul et al., (2001) ${ }^{18,19}$. These studies have shown that significant proportion of elderly patients were unable to recover to their pre-fracture level of ADL.

Feeding or eating was shown to be the activity with the highest independent level, while, bathing has the lowest independent level among hip fracture patients ${ }^{15,16}$. These results were supported by Morris \& Morris (1997), which described that bathing, was the first activity in ADL that was lost, while eating was the last to be retained after a hip fracture ${ }^{21}$. Heikkinen \& Jalovaara (2005) had assessed functional outcome of hip fracture patients using questionnaire that contain only 4 basic ADL (bathing, dressing, feeding and toileting). It was shown that after four months of hip fracture, the 'bathing activity' of the patients did not improve and remain unchanged ${ }^{22}$. However, it was pointed out that different type and structure of bathing accommodations may influence the outcome of 'bathing activity' during the assessment of $A D L^{15}$.

Three articles from this review, including the study with over 7000 subjects, showed that the level of 
dependent was increased in hip fracture patients $16,17,18$. This finding was in agreement with the study by Dailiana et al., (2013) which reported that one year after a hip fracture, half of the patients failed to achieve full recovery of their $A D L$ function ${ }^{23}$. Other studies using different tools to assess ADL also found that hip fracture was associated with increased dependence of $\mathrm{ADL}^{24}$. Based on the Standardised Audit Guideline Recommended for Europe (SAHFE) to evaluate functional ability and $A D L$, it was shown that $60 \%$ of patients require assistance to perform their ADL after a hip fracture ${ }^{25}$. In another study by Alarcon et al., (2011), hip fracture patient was followed-up for two years and their ADL assessed using Barthel Index. It was found that $78 \%$ of patients recovered their ADL after three months of hip fracture injury ${ }^{26}$.

This result supported the findings of the two articles included in this systematic review, which found that $60.8 \%$ of patients achieved their basic pre-fracture ADL level after one year of hip fracture ${ }^{19}$ and $78 \%$ were able to perform all Katz ADL independently after six month of fracture ${ }^{15}$. In contrast, Koval \& Zuckerman (1994) reported that after one year of hip fracture, the elderly patients failed to recover their ability to perform either basic or instrumental $\mathrm{ADL}$ as before the fracture ${ }^{27}$. Boyd et al., (2008) studied the ability of elderly with hip fracture to recover their $A D L$ after being discharged from the hospital. It was shown that at 1 year, only $30 \%$ of them have the ability to return back to their preadmission level of self-care $\mathrm{ADL}^{28}$. These findings were in agreement with the other three studies included this review which also found that elderly patients failed to fully recover their basic ADL at 1 year post-fracture ${ }^{16,17,19}$. Wollinsky et al., (1997) which followed up more than 7000 patients, showed that six years after a hip fracture, the patients had experience a significant increase in mean difficulties of basic $A L^{18}$. Curry et al., (2003) showed high percentage of independence in ADL with 18 out of 23 patients becoming independent at least six month after fracture. However, the samples size of the study was small and most subjects had lived independently before fracture, which may have contributed to the high rate of recoveries ${ }^{15}$.

There are several factors that may affect the functional recovery of hip fracture patients. One of the most important factors is the patient's age. The chances of full functional recovery declined with age. Other factors include chronic disease, acute cognitive deficit post-surgery, ability to walk before fracture, depression, living alone, prolonged hospitalization and living in nursing homes ${ }^{29}$. Study by Mehul et al., (2001) showed that the ADL recovery level was related to the patient's age. Relatively older patients were more dependent compared to younger patients. In the study, the number of patients aged 89 years or below was very high (774 patients) as compared to those aged more than 90 years old (76 patients). The huge difference in age category may influence the results which showed that nearly $61 \%$ of the patients recovered to their pre-fracture ADL level ${ }^{19}$. Tinetti et al., (1999) had assessed ADL of elderly hip fracture patients using another type of assessment tool called Occupational Therapy Functional Assessment Compilation (OTFACT). They were able to show that the recovery rates of $A D L$ among hip fracture patients within the year following fracture were around $25 \%$ to $50 \%^{30}$. This finding proved that old age is one of the risk factors for poor functional recovery after experiencing a hip fracture. Similar findings were reported by several other studies in elderly hip fracture patients using different ADL assessment tools. Infante-Catro et al., (2013) showed that age was an important predictor for functional recovery in elderly subjects ${ }^{31}$. Magaziner et al., (2003) also showed that aging contributed to disability in ADL among hip fracture patients after one year of the incident ${ }^{12}$.

As for the studies included in this systematic review, Wollinsky et al (1997) did not examine the relationship between the patient's age and ADL status, but just compared the ADL level between hip fracture patients and control subjects ${ }^{18}$. Two other studies showed no association between age and ADL status ${ }^{15,17}$ while, another two studies showed an association between ADL with age ${ }^{16,19}$. There was a decline in functional status of patients above 80 years old ${ }^{16}$ and patients above 90 years old were more likely to have lower ADL score ${ }^{19}$.

As for the gender differences, four studies in this systematic review included both male and female subjects ${ }^{16,17,18,19}$. However, only the study by Garcia et al., $(2006)^{16}$ had managed to compare the ADL score of both sexes while the other three study did not make any attempt to compare them ${ }^{17,18,19}$. It was shown that male sex was associated with the decline in functional status ${ }^{16}$. The result differed from a previous study by Endo et al., (2005) which showed no significant gender difference in ADL score among hip fracture patients ${ }^{32}$. Hawkes et al., (2006) also concluded that the functional recovery status after fracture for men was probably the same to women ${ }^{33}$. Furthermore, Samuelson et al., (2009) also showed no association between gender and ADL status $^{34}$.

\section{CONCLUSION}

Elderly patients with hip fracture had experienced a decline in ADL with a significant proportion of the patients failed to recover their pre-fracture ADL functional status. There is still not enough evidence to conclude whether age and gender would have any significant affect on ADL status. More studies on ADL status on hip fracture are required.

\section{ACKNOWLEDGEMENT}

This work was supported by Universiti Kebangsaan Malaysia using Dana Impak Perdana Grant [DIP-2013002]. 


\begin{tabular}{|c|c|c|c|c|c|c|}
\hline Title & Authors & $\begin{array}{l}\text { Study } \\
\text { Design }\end{array}$ & $\begin{array}{l}\text { Year of } \\
\text { publication }\end{array}$ & $\begin{array}{l}\text { Sample or } \\
\text { subject }\end{array}$ & $\begin{array}{l}\text { Method } \\
\text { of ADL } \\
\text { assessment }\end{array}$ & Results \\
\hline $\begin{array}{l}\text { Evolution } \\
\text { of } \\
\text { Brazilian } \\
\text { elderly } \\
\text { with hip } \\
\text { fracture } \\
\text { secondary } \\
\text { to a fall }\end{array}$ & $\begin{array}{l}\text { Garcia } \\
\text { et al., } \\
{[16]}\end{array}$ & $\begin{array}{l}\text { Retrospective } \\
\text { Descriptive } \\
\text { Study }\end{array}$ & 2006 & $\begin{array}{l}\text { Sample size: } \\
34 \text { patients } \\
\text { Sex: } 29 \text { men } \\
\text { and } 5 \\
\text { women. } \\
\text { Age of } \\
\text { subjects: } 60 \\
\text { to } \\
100 \text { years } \\
\text { old. }\end{array}$ & $\begin{array}{l}\text { Duration of } \\
\text { follow up: } 1 \\
\text { year after } \\
\text { fracture } \\
\text { Patients were } \\
\text { contacted via } \\
\text { email or } \\
\text { telephone } \\
\text { and, home } \\
\text { visits. } \\
\text { All subjects } \\
\text { were } \\
\text { interviewed. } \\
\text { Relative or } \\
\text { caregivers } \\
\text { were } \\
\text { interviewed } \\
\text { if subjects } \\
\text { have cognitive } \\
\text { impairment. }\end{array}$ & $\begin{array}{l}\text { ADL Before fracture: } \\
30 \% \text { of samples were } \\
\text { dependent in the activity of } \\
\text { bathing, } 18 \% \text { in dressing and } \\
\text { toileting, } 12 \% \text { in physical } \\
\text { ambulation, } 36 \% \text { in } \\
\text { urinary/faecal continence } \\
\text { and } 9 \% \\
\text { in feeding. The most } \\
\text { dependent basic daily living } \\
\text { activity was urinary/faecal } \\
\text { continence. } \\
\text { ADL one year after } \\
\text { fracture: } \\
\text { The level of dependent on } \\
\text { the basic daily living activity } \\
\text { for each items were bathing } \\
55 \% \text {, dressing and toileting } \\
48 \% \text {, physical ambulation } \\
45 \% \text {, urinary/faecal } \\
\text { continence } 68 \% \text { and feeding } \\
26 \%\end{array}$ \\
\hline $\begin{array}{l}\text { Prediction } \\
\text { of the } \\
\text { outcome } \\
\text { after hip } \\
\text { fracture in } \\
\text { elderly } \\
\text { patients }\end{array}$ & $\begin{array}{l}\text { Svensson } \\
\text { et al., } \\
{[17]}\end{array}$ & $\begin{array}{l}\text { Prospective } \\
\text { study }\end{array}$ & 1996 & $\begin{array}{l}\text { Sample size: } \\
232 \text { patients } \\
\text { Sex: } 179 \\
\text { women and } \\
53 \text { men. } \\
\text { Age of sub- } \\
\text { jects: } 65 \text { to } \\
96 \text { years } \\
\text { old. }\end{array}$ & $\begin{array}{l}\text { Duration of } \\
\text { follow up: } 1 \\
\text { year after } \\
\text { fracture } \\
\text { ADL function } \\
\text { assessed at the } \\
\text { time of prein- } \\
\text { jury and one } \\
\text { year after } \\
\text { fracture. } \\
\text { ADL function } \\
\text { was graded as } \\
\text { Good or } \\
\text { Dependant. } \\
\text { Good ADL } \\
\text { meant that } \\
\text { patients were } \\
\text { at least able to } \\
\text { dress and } \\
\text { undress } \\
\text { independently. }\end{array}$ & $\begin{array}{l}\text { ADL before fracture: } \\
205 \text { patients }(88 \%) \text { were in } \\
\text { Good ADL function while } 27 \\
\text { patients (12\%) were } \\
\text { Dependent in ADL function. } \\
\text { ADL at one year after } \\
\text { fracture: } \\
\text { After one year, } 81 \% \text { were } \\
\text { good in ADL function and } \\
33 \% \text { were Dependent in ADL } \\
\text { function. }\end{array}$ \\
\hline
\end{tabular}




\begin{tabular}{|c|c|c|c|c|c|c|}
\hline $\begin{array}{l}\text { The effect of } \\
\text { hip fracture on } \\
\text { mortality, } \\
\text { hospitalization, } \\
\text { and functional } \\
\text { status: A } \\
\text { prospective } \\
\text { study }\end{array}$ & $\begin{array}{l}\text { Wollinsky } \\
\text { et al., } \\
{[18]}\end{array}$ & $\begin{array}{l}\text { Prospective } \\
\text { longitudinal } \\
\text { study }\end{array}$ & 1997 & $\begin{array}{l}\text { Sample size: } 7527 \\
\text { subjects; hip } \\
\text { fracture patients } \\
\text { ( } 368) \text { and control } \\
\text { subjects (7159). } \\
\text { Age of subjects :70 } \\
\text { years old or more } \\
\text { Assessment at } \\
\text { baseline and } 8 \\
\text { years follow up. } \\
\text { At } 8 \text {-years follow- } \\
\text { up: left with } 4138 \\
\text { subjects; } 108 \text { hip } \\
\text { fracture patients } \\
\text { and } 4030 \text { controls }\end{array}$ & $\begin{array}{l}\text { Duration of } \\
\text { follow up: } \\
\text { Baseline and } \\
\text { followed up } \\
\text { prospectively } \\
\text { up to } 8 \text { years. } \\
\text { Patients were } \\
\text { interviewed } \\
\text { for ADL } \\
\text { assessment. }\end{array}$ & $\begin{array}{l}\text { ADL at Baseline: } \\
\text { Hip fracture patients } \\
\text { and control subjects } \\
\text { have mean difficulties } \\
\text { in Basic ADL of } \\
0.78 \text { and } 0.68 \text {, } \\
\text { respectively. } \\
\text { ADL at the time of } \\
\text { follow up: } \\
\text { Mean difficulties in } \\
\text { Basic ADL for hip } \\
\text { fracture patients and } \\
\text { control subjects were } \\
2.07 \text { and } 0.79 \\
\text { respectively. } \\
\text { The significant } \\
\text { increase of mean } \\
\text { difficulties in Basic } \\
\text { ADL indicated new } \\
\text { functional limitations } \\
\text { for elderly hip } \\
\text { fracture patients. }\end{array}$ \\
\hline $\begin{array}{l}\text { Outcome after } \\
\text { hip fracture in } \\
\text { individuals } \\
\text { ninety years of } \\
\text { age and older }\end{array}$ & $\begin{array}{l}\text { Mehul et } \\
\text { al., [19] }\end{array}$ & $\begin{array}{l}\text { Prospective, } \\
\text { Consecutive }\end{array}$ & 2001 & $\begin{array}{l}\text { Sample size: } 850 \\
\text { Sex: } 616 \text { female } \\
\text { and } 158 \text { male. } \\
\text { Age: } 65 \text { to } 105 \\
\text { years of age. } \\
\text { At } 1 \text { year follow } \\
\text { up, only } 602 \\
\text { patients left }\end{array}$ & $\begin{array}{l}\text { Duration of } \\
\text { follow up: } 1 \\
\text { year after } \\
\text { fracture. } \\
\text { Patients' } \\
\text { pre- fracture } \\
\text { ADL were } \\
\text { assessed and } \\
\text { then followed } \\
\text { up one year } \\
\text { after fracture. } \\
\text { Patients, } \\
\text { family } \\
\text { members or } \\
\text { caregivers } \\
\text { were inter- } \\
\text { viewed during } \\
\text { admission. } \\
\text { Follow up was } \\
\text { carried out by } \\
\text { telephone } \\
\text { interview. }\end{array}$ & $\begin{array}{l}\text { ADL before fracture: } \\
92 \text { patients aged } 65 \\
\text { to } 89 \text { years old } \\
\text { (11.9\%) were } \\
\text { dependent in at least } \\
\text { one Basic ADL. } \\
23 \text { patients, aged } \\
\text { more than } 90 \text { years } \\
\text { old ( } 30.3 \%) \text { were } \\
\text { dependent on at least } \\
\text { one basic ADL. } 682 \\
\text { patients ( } 88.1 \%) \\
\text { aged } 65 \text { to } 89 \text { years } \\
\text { old and } 53 \text { patients } \\
\text { (69.7\%) aged more } \\
\text { than } 90 \text { years old } \\
\text { were dependent in all } \\
\text { basic ADL. } \\
\text { Patients more than } 90 \\
\text { years old were more } \\
\text { dependent in basic } \\
\text { ADL. } \\
\text { ADL one year after } \\
\text { fracture: } \\
480 \text { ( } 60.8 \%) \text { patients } \\
\text { recovered to their } \\
\text { pre-fracture level of } \\
\text { independence in Basic } \\
\text { ADL. Patients more } \\
\text { than } 90 \text { years old } \\
\text { showed more } \\
\text { deterioration in basic } \\
\text { ADL compared to } \\
\text { patients aged } \\
\text { between } 65 \text { to } 89 \\
\text { years old. }\end{array}$ \\
\hline
\end{tabular}




\section{CONFLICT OF INTEREST}

The authors reported no conflicts of interest.

\section{REFERRENCES}

1. Gold DA. An examination of instrumental activities of daily living assessment in older adults and mild cognitive impairment. Journal of clinical and experimental neuropsychology 2012; 34:11-34.

2. Reijneveld S, Spijker J, Dijkshoorn H. Katz' ADL Index Assessed Functional Performance of Turkish, Moroccan and Dutch Elderly. Journal of Clinical Epidemiology 2007; 60: 382-388.

3. Wallace M, Shelkey M. Katz Index of Independence in Activities of Daily Living. J Gerontol Nurs 1999; 25: 8-9.

4. Cheah E, Rajaram S, Chua HC et al. Managing Functional Decline Among Elderly Patients In ward 3 Geriatric Ward using the Katz Index Of Independence In Activities of Daily Living (ADL). BMJ Supportive \& Palliative Care 2011; 1: 9495.

5. LaPlante MP. The Classic Measure of Disability in Activities of Daily Living Is Biased by Age but an Expanded IADL/ADL Measure Is Not. Journal of Gerontology: Social Sciences 2010; 65:720732.

6. Mittal R, Banerjee S. Proximal femoral fractures: Principle of management and review of literature. Journal of Clinical Orthopaedics and trauma; 3:15-23.

7. Butler M, Forte M, Kane RL, Joglekar S, Duval SJ, Swiontkowski M, et al. Treatment of Common Hip Fractures [Internet]. [US]: Agency for Healthcare Research and Quality; 2009 [cited 2016 January 16]. Available from: http://www.ncbi.nlm.nih.gov/books/ NBK32591/pdf/Bookshelf_NBK32591.pdf.

8. Ftouh S, Morga A, Swift C. Management of hip fracture in adults: summary of NICE guidance. BMJ 2011; 342: 1-3.

9. Koval KJ, Zuckerman JD. Hip Fracture: I. Overview and Evaluation and Treatment of Femoral Neck Fracture. J Am Acad Orthop Surg 1994; 2: 141-149.

10. Dinesh KD, Elaine MD, Nick CH, Cyrus C. Epidemiology of hip fracture: worldwide geographic variation. Indian J Orthop 2011; 45:15-22.

11. Lee JK, Amir SMK. The incidence of hip fracture in Malaysians above 50 years of age; variation in different ethnic groups. APLAR Journal of Rheumatology 2007; 10:300-305.

12. Magaziner J, Fredman L, Hawkes W et al. Changes in Functional Status Attributable to Hip Fracture: A Comparison of Hip Fracture Patients to Community-dwelling Aged. American Journal of Epidemiology 2003; 153:1023-1031.

13. Tazona-Santabalbina FK, Belenguer-Varea A, Rovira-Daudi E. Early Interdisciplinary hospital Intervention for Elderly Patients with Hip fracture - Functional Outcome and Mortality.
CLINICS 2012; 67:547-555.

14. Chudyk AM, Jutai JW, Petrella RJ, and Speechley M. Systematic Review of Hip Fracture Rehabilitation Practices In the Elderly. Arch Phys Med Rehabil 2009; 90:246-262.

15. Curry LC, Hogstel MO, Davis GC. Functional status in older women following hip fracture. Journal of Advanced Nursing 2003; 42:347-354.

16. Garcia R, Leme MD, Garcez-Leme LE. Evolution of Brazilian Elderly with Hip Fracture Secondary to a Fall. CLINICS 2006; 61:539-544.

17. Svensson O, Stromberg L, Ohlen G, Lindgren U. Prediction of the outcome after hip fracture in elderly patients. J Bone Joint Surg Br 1996; 78: 115-118.

18. Wollinsky FD, Fitzgerald JF, Stump ES. The Effect of Hip Fracture on Mortality, Hospitalization, and Functional Status: A Prospective Study. American Journal of Public Health 1997; 87:398-403.

19. Mehul RS, Gina BA, Philip W, Joseph DZ, Kenneth JK. Outcome After Hip fracture in individuals Ninety years of Age and Older. Journal of Orthopaedic Trauma 2001; 15: 3439.

20. International osteoporosis foundation. Fact and Statistics about osteoporosis and its impact. Journal of Bone and Mineral research 2009; 4: 113-118.

21. Morris JN, Morris SA. ADL assessment measures for use with frail elders. Journal of Mental Health and Aging 1997; 3:19-45.

22. Heikkinen T, Jalovaara P. Four or Twelve Months Follow-Up in the Evaluation of functional Outcome After Hip fracture Surgery?. Scandavian journal of Surgery 2005; 94: 59-66.

23. Dailiana Z, Papakostidou I., Varitimidis S, Michalitsis SG, Veloni A, Malizos KN. Surgical treatment of hip fractures: factors influencing mortality. HIPPOKRATIA 2013; 17:252-257.

24. Neuman MD, Silber JH., Magaziner J, Passarella MA, Mehta S, Werner RM. Survival and Functional Outcomes After hip Fracture Among Nursing Home residents. JAMA Intern Med 2014; 174:1273-1280.

25. Rosell PAE, Parker MJ. Functional Outcome after Hip Fracture A 1- Year Prospective Outcome Study of 275 Patients. Injury, Int J. Care Injured 2003; 34:529-532.

26. Alarcon T, Gonzalez-Montalvo JI, Gotor P, Madero R, Otero A. Activities of daily living after hip fracture: profile and rate of recovery during 2 years of follow-up. Osteoporos Int 2011; 22: 1609-1613.

27. Koval KJ, Zuckerman JD. Current Concept review Functional Recovery after fracture of the hip. The Journal of Bone and Joint Surgery, Incorporated 1994; 76:752-758.

28. Boyd CM, Landefeld S, Cousell SR et al. Recovery in activities of daily living among 
older adults following hospitalization for acute medical illness. J Am Geriatr soc 2008; 56:21712179.

29. Lin PC, Chang SY. Functional Recovery Among Elderly People One Year After Hip Fracture Surgery. Journal of Nursing Research 2004; 1:72 -82 .

30. Tinetti ME, Baker DI, Gottschalk M et al. HomeBased Multicomponent Rehabilitation Program for Older Person After hip Fracture: A Randomized Trial. Arch Phys Med Rehabil 1999; 80:916-922.

31. Infante-Castro $\mathrm{Cl}$, Rojano-Mejia D, Ayala-Vazque G, Aguilar-Espanza G. Functional prognostic factors in older adults with hip fracture. Cir $\mathrm{Cir}$ 201;. 81:117-121.

32. Endo $Y$, Aharonoff GB, Zuckerman JD, Egol KA, Kova KJ. Gender Differences in Patients With Hip fracture: A Greater Risk of Morbidity and Mortality in Men. J Orthop Trauma 2005; 19:2935.

33. Hawkes WG, Wehren L, Orwing D, Hebel JR, Magaziner J. Gender differences in Functioning after hip fracture. J.Gerontol A. Biol Sci Med Sci 2006; 61:495-499.

34. Samuelsson B, Hedstorm MI, Ponzer S et al. Gender Difference and Cognitive Aspects on functional outcome after hip fracture - 12 years follow-up of 2134 patients. Age and Ageing 200;. 38: 686-692. 